\title{
Forms of Communication Practice in Social Conflict Mitigation Using Qualitative Content Analysis
}

\author{
M. Isnaini ${ }^{1}$ \\ \{isnaini@budiluhur.ac.id\}
}

Faculty of Communication, Universitas Budi Luhur, Jl. Ciledug Raya, Jakarta, Indonesia ${ }^{1}$

\begin{abstract}
This study aimed to identify forms of communication practice in social conflict mitigation. The research used qualitative approach with qualitative content analysis method. The study used secondary data in the form of news text about social conflict sourced from online media. Data analysis using NVivo 11Plus software. The results showed: forms of communication practice are socialization, collective action, gathering information, and dialogue.That forms of communication practice can be used as an instrument of mitigating social conflict .
\end{abstract}

Keywords: Conflict, social, mitigation, communication.

\section{Introduction}

Jakarta should appear as a friendly and livable city. This is because Jakarta as a barometer for other cities in Indonesia, to realize hospitality as well as a livable city is not an easy matter. Since Jakarta officially became the province and capital of the country in 1961, various problems have emerged. Unplanned and overlapping urban spatial planning, high levels of urbanization, and poor environmental carrying capacity, make Jakarta as a prone city.

The National Unity and Politics Institution Badan Kesatuan Bangsa dan Politik DKI Jakarta/BKBPJakarta (2015) mentions several objective conditions faced by Jakarta people which has the potential to become threats, challenges, obstacles, and disturbances, such as: 1) Jakarta as the capital of the state is a center of political and power interests in government [1]. This situation makes Jakarta vulnerable to all impacts arising from political life in Indonesia; 2) Jakarta people is a pluralistic society consisting of various ethnic, racial, religious, and class. This situation makes social interaction in Jakarta very complex and dynamic; 3) a prolonged multi-dimensional crisis makes people's lives tough. This situation ultimately almost eliminates public confidence in the sense of hope for a better future.

These obstacles and disorders, if not well addressed, can lead to the emergence of social conflict. Such conflicts can result in loss of security, fear, environmental damage, property loss, loss of life, and psychological trauma of the people (revenge, hatred, anti-starch, etc.), thus inhibiting overall development.

Jakarta is inhabited by 10,177 million people spread in 44 sub-districts and 267 urban villages [2]. The mapping of BKBP Jakarta (2015) shows that there are 16 sub-districts in Jakarta that are prone to conflict [1]. These sub-districts include: Kebayoran Baru Sub-district, Tebet Sub-district, Mampang Prapatan Sub-district, and Setia Budi Sub-district in South Jakarta; Kramat Jati sub-district, Jatinegara sub-district, and Matraman sub-district in East Jakarta; Grogol Petamburan Sub-district, Cengkareng Sub-district, and Tambora Sub-District 
in West Jakarta; Johar Baru and Gambir sub-districts in Central Jakarta; Penjaringan Subdistrict, Pademangan Sub-district, Koja Sub-district, and Cilincing Sub-District in North Jakarta. The causes of such conflicts include poverty, population density, crime, slums, and brawl [1]

Social conflicts that have become the daily menu of citizens in Jakarta put forward clearly [3]. In one of the urban villages in Jakarta, in Tanah Tinggi, Tadie (2009) clearly illustrates how violence and conflict occurred as follows: [3]

"Areas of violence in Tanah Tinggi are in plain view. This occurs because of populations located in the legality border: Inter-village fights which often get people wounded or even killed, vigilante mobs - burning police stations or burglars - and criminal acts by delinquent."

Efforts to cope with social conflicts in Jakarta have been done frequently. Whether through mediation or settlement with legal involved for the conflict doer that are indicated to commit a crime.Sumarno (2014) found that one of the efforts to mitigate social conflicts is by establishing citizens' forums, such as the Forum Kewaspadaan Dini Masyarakat, Kelompok Sadar Masyarakat, and Komunitas Kampung Aman [4].

Several studies have found the importance of communication in conflict mitigation. Nisa (2015) mentioned in the perspective of communication, the most important conflict resolution is the desire to resolve conflicts from the parties involved in the conflict [5]. Ardiyanti (2014) states that the appropriate selection of mediators and the identification of verbal and nonverbal languages used in the communication process define successful negotiations in conflict mitigation [6].

Based on the background exposure, then the formulation of the problem in this study are: what is the forms of communication practice in mitigating social conflict?

Based on the problem formulation above, the purposes of this research are to identify forms of communication practice in mitigating social conflict.

\section{Research Methods}

The research examines communication practices in mitigating social conflict uses a qualitative approach. According to Creswell (2016), the characteristics of qualitative research are: (a) the natural environment; (b) the researcher as a key instrument; (c) various data sources; (d) inductive and deductive data analysis; (e) meaning from the participants; (f) a developing plan; $(\mathrm{g})$ reflexivity; and $(\mathrm{h})$ a holistic view [7].

This research using qualitative content analysis method. Hsieh and E.Shannon (2005) explains that qualitative content analysis is one of methods used to analyze text data.Elo and Kyngäs (2008) says that content analysis have disadvantage relates to research questions that are ambiguous [8],[9].

The data used in this study is secondary data in the form of news text about social conflict sourced from online media [10]. when analysing qualitative data, it does not just identify the data, but also contextualising and making connections between those theme. Therefore, to facilitate the analysis, this study using NVivo 11 plus software. Welsh (2002) says that Nvivo could be used when dealing with qualitative data [11]. Similar to Welsh, Hilal and Alabri (2013) and Leech and Onwuegbuzie(2011) also express the same thing about Nvivo when analysing qualitative data [12],[13]. 
According to Praharsi (2006), the researcher is the main instrument of analysis in qualitative research. Nvivo only presents raw data that has been organized in accordance with the needs of researchers [14].

In addition, to get the relations between research subjects including communication practices and mitigation of social conflict. The news text is presented in table 1 below:

Table 1. News text of online media.

\begin{tabular}{|c|c|c|c|}
\hline No & Title & Source & Year \\
\hline 1 & $\begin{array}{l}\text { Social } \\
\text { Minister: Our } \\
\text { Main Problem } \\
\text { is Poverty and } \\
\text { Inharmoniousl } \\
\text { y Social }\end{array}$ & $\begin{array}{l}\text { http://nasional.komp } \\
\text { as.com/read/2016/0 } \\
\text { 4/13/08170031/Men } \\
\text { sos.Problem.Utama. } \\
\text { Kita.adalah.Kemiski } \\
\text { nan.dan.Ketidakhar } \\
\text { monisan.Sosial }\end{array}$ & 2016 \\
\hline 2 & $\begin{array}{l}\text { Unravelling } \\
\text { the Fights in } \\
\text { Johar Baru }\end{array}$ & $\begin{array}{l}\text { http://megapolitan.k } \\
\text { ompas.com/read/20 } \\
\text { 15/07/27/14400201/ } \\
\text { Mengurai.Tawuran. } \\
\text { di.Johar.Baru }\end{array}$ & 2015 \\
\hline 3 & $\begin{array}{l}\text { Story of } \\
\text { Central Jakarta } \\
\text { Mayor in } \\
\text { Confuse to } \\
\text { Finish the } \\
\text { Fights in Johar } \\
\text { Baru }\end{array}$ & $\begin{array}{l}\text { http://megapolitan.k } \\
\text { ompas.com/read/20 } \\
\text { 15/09/09/16320881/ } \\
\text { Cerita.Wali.Kota.Ja } \\
\text { karta.Pusat.Kebingu } \\
\text { ngan.Selesaikan.Ta } \\
\text { wuran.di.Johar.Baru }\end{array}$ & 2015 \\
\hline 4 & $\begin{array}{l}\text { To Cope With } \\
\text { the Fights } \\
\text { That Become } \\
\text { a "Culture" in } \\
\text { Manggarai }\end{array}$ & $\begin{array}{l}\text { http://megapolitan.k } \\
\text { ompas.com/read/20 } \\
\text { 17/03/09/10573121/ } \\
\text { mengentaskan.tawur } \\
\text { an.yang.menjadi.bu } \\
\text { daya.di.manggarai }\end{array}$ & 2017 \\
\hline 5 & $\begin{array}{l}\text { The Capital } \\
\text { City is } \\
\text { Vulnerable to } \\
\text { Social Conflict }\end{array}$ & $\begin{array}{l}\text { http://www.koran- } \\
\text { jakarta.com/ibu- } \\
\text { kota-rentan-konflik- } \\
\text { sosial/ }\end{array}$ & 2017 \\
\hline 6 & $\begin{array}{l}\text { Johar Baru to } \\
\text { Become a } \\
\text { Social } \\
\text { Laboratory }\end{array}$ & $\begin{array}{l}\text { https://m.tempo.co/r } \\
\text { ead/news/2011/08/2 } \\
\text { 3/082353068/johar- } \\
\text { baru-akan-jadi- } \\
\text { laboratorium-sosial }\end{array}$ & 2017 \\
\hline 7 & $\begin{array}{l}\text { Citizen } \\
\text { Forums to } \\
\text { Prevent } \\
\text { Manggarai's } \\
\text { Strikes }\end{array}$ & $\begin{array}{l}\text { http://www.jawapos } \\
\text {.com/read/2017/03/ } \\
\text { 14/115943/bentuk- } \\
\text { forum-warga-untuk- } \\
\text { cegah-tawuran- } \\
\text { manggarai }\end{array}$ & 2017 \\
\hline 8 & $\begin{array}{l}\text { Important } \\
\text { Role of } \\
\text { FKDM to } \\
\text { Prevent Social }\end{array}$ & $\begin{array}{l}\text { http://suarajakarta.c } \\
\text { o/news/penting- } \\
\text { peran-fkdm-dalam- } \\
\text { mencegah-konflik- }\end{array}$ & 2016 \\
\hline
\end{tabular}




\begin{tabular}{|c|c|c|c|}
\hline \multirow{4}{*}{9} & Conflict & sosial-di- & \multirow{4}{*}{2016} \\
\hline & Frequent & $\begin{array}{l}\text { masyarakat/ } \\
\text { http://mediaindonesi }\end{array}$ & \\
\hline & Fights, Johar & a.com/news/read/42 & \\
\hline & Baru & 998/sering-tawuran- & \\
\hline \multirow[b]{2}{*}{10} & $\begin{array}{l}\text { Residents to } \\
\text { be Relocated } \\
\text { to Rusun }\end{array}$ & $\begin{array}{l}\text { warga-johar-baru- } \\
\text { akan-direlokasi-ke- } \\
\text { rusun/2016-04-28 }\end{array}$ & \multirow[b]{2}{*}{2011} \\
\hline & $\begin{array}{l}\text { Johar Baru, } \\
\text { 'The Bronx of } \\
\text { Jakarta' }\end{array}$ & $\begin{array}{l}\text { http://metropolitan.i } \\
\text { nilah.com/read/detai } \\
\text { 1/1784352/johar- } \\
\text { baru-the-bronx-of- } \\
\text { jakarta }\end{array}$ & \\
\hline 11 & $\begin{array}{l}10 \text { Sub- } \\
\text { District in } \\
\text { Jakarta is } \\
\text { prone to social } \\
\text { conflicts }\end{array}$ & $\begin{array}{l}\text { https://www.merdek } \\
\text { a.com/jakarta/10- } \\
\text { kelurahan-di- } \\
\text { jakarta-ini-rawan- } \\
\text { terjadi-konflik- } \\
\text { sosial.html }\end{array}$ & 2014 \\
\hline \multirow[t]{4}{*}{12} & Early & http://www.harnas.c & \multirow[t]{4}{*}{2017} \\
\hline & Detection for & $\mathrm{o} / 2017 / 03 / 15 /$ deteks & \\
\hline & the Potential & i-dini-potensi- & \\
\hline & Conflict & & \\
\hline \multirow[t]{3}{*}{13} & Social & http://news.liputan6. & \multirow[t]{3}{*}{2017} \\
\hline & $\begin{array}{l}\text { Minister: } \\
\text { social gap }\end{array}$ & $\begin{array}{l}\text { com/read/2838496/ } \\
\text { mensos- }\end{array}$ & \\
\hline & $\begin{array}{l}\text { triggers social } \\
\text { conflicts }\end{array}$ & $\begin{array}{l}\text { kesenjangan-sosial- } \\
\text { picu-meningkatnya- } \\
\text { potensi-konflik }\end{array}$ & \\
\hline \multirow[t]{7}{*}{14} & BIN assessed & https://nasional.tem & \multirow[t]{7}{*}{2017} \\
\hline & Local & po.co/read/news/20 & \\
\hline & Government & $17 / 03 / 15 / 07885634$ & \\
\hline & Late in Cope & 0/bin-nilai-pemda- & \\
\hline & With Social & kerap-terlambat- & \\
\hline & Conflict & tangani-gejala- & \\
\hline & Symptoms & konflik-sosial & \\
\hline \multirow[t]{5}{*}{15} & Lampung, & http://nasional.news & \multirow[t]{5}{*}{2015} \\
\hline & East Java, and & .viva.co.id/news/rea & \\
\hline & Jakarta are & d/702195-lampung- & \\
\hline & Vulnerable to & jawa-timur-dan- & \\
\hline & Social Conflict & $\begin{array}{l}\text { jakarta-rentan- } \\
\text { konflik-sosial }\end{array}$ & \\
\hline \multirow[t]{7}{*}{16} & Though in few & https://www.gatra.c & \multirow[t]{7}{*}{2016} \\
\hline & number, the & om/politik/pemilu/p & \\
\hline & Potential of & ilkada/200010- & \\
\hline & Social Conflict & meski-kecil-potensi- & \\
\hline & in Jakarta & konflik-sosial-di- & \\
\hline & Need to Be & jakarta-perlu- & \\
\hline & Watched & diwaspadai & \\
\hline \multirow[t]{3}{*}{17} & West Jakarta & http://www.rmoljak & \multirow[t]{3}{*}{2015} \\
\hline & Apparatus & arta.com/read/2015/ & \\
\hline & Cooperate & 07/24/10376/Aparat & \\
\hline
\end{tabular}




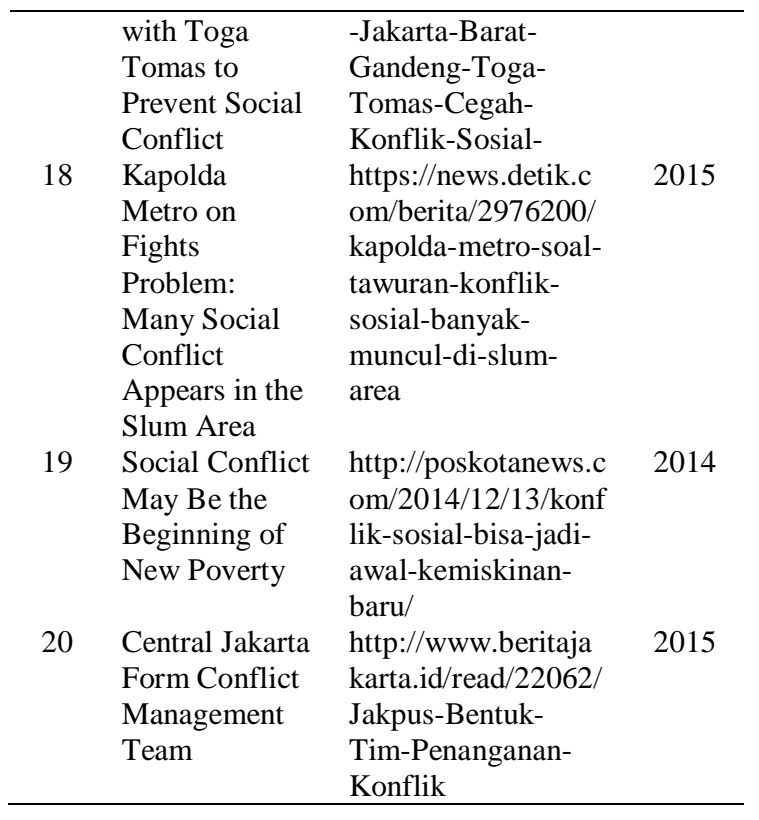

\section{Results And Discussion}

Analysis of this research data is assisted by devices NVivo 11 Plus software. According to Bandur (2016) in qualitative research analysis, NVivo software help researchers to ensure that data is sourced from the field, so it contains the high validity data [15].

After all the data collected, the researcher enter the data into NVivo so that data management can be better and orderly. Advantages of NVivo in data management is, if there is addition or modification of data, researchers will not need to fear that the data will be changed, because the data is inputted automatically, then if modified later on, NVivo will also record the data.

Qualitative research requires accuracy in reading data in order to make the categorization properly. Using the facility of nodes provided by NVivo, the process of reading and encoding data can be done easily, quickly, and accurate. According to Bandur (2016), nodes have an important role in the management and analysis of qualitative data using Nvivo [15]. The nodes presented in Fig 1 below: 


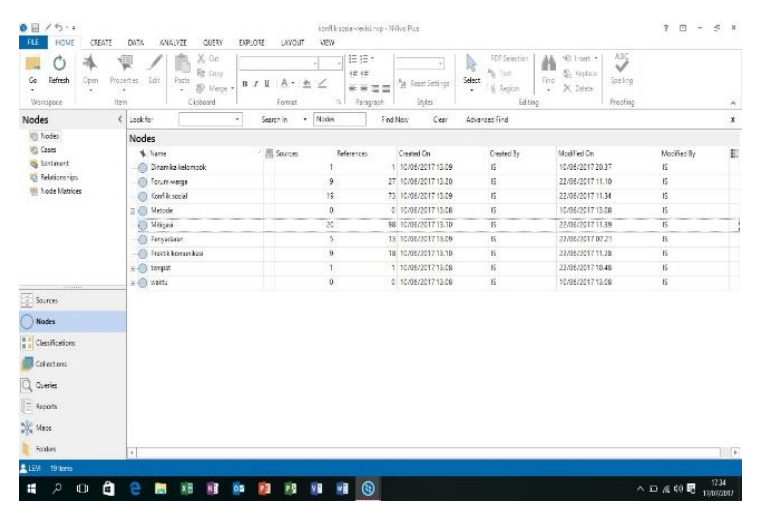

Fig. 1. Nodes Research.

Nodes are then applied when the researchers coded over 20 news texts from online media.

\subsection{Form of Social Conflict in Jakarta}

The coding results of nodes on social conflict from online news texts resulted in frequent forms of social conflict: clashes between citizens, raids, parking lot disputes, and conflicts with security personnel. Although there are other forms of social conflict, such as torture and demonstration, the proportions of which are small. Understanding the forms of social conflict that often occur will facilitate the kind of mitigation steps to do. Therefore, every form of social conflict requires different handling. Visualization of the forms of social conflict using the concept map is presented in Figure 2 below:

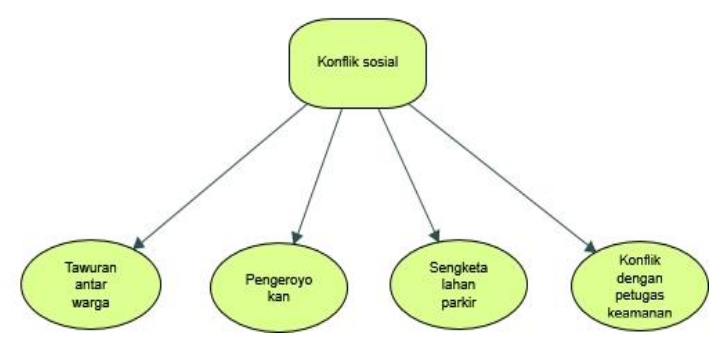

Fig. 2. Concept Map of Social Conflict Forms.

Of the 20 news texts studied, brawl among the citizens is a form of social conflict that often appear, followed by gang up fights, land dispute parker, and conflicts with security officers. This shows that brawl between residents dominates the social conflict in Jakarta. This is in line with Tadie's (2009) view that brawl between people or between groups is the most common form of social conflict, especially in areas with high levels of poverty and density such as in Johar Baru, Central Jakarta or Manggarai, South Jakarta. 
According to article 10 and Article 11 of Law No. 7 Year 2012 on Handling Social conflicts mention the early warning system of conflict. The early warning system is part of conflict mitigation. Other conflict mitigation activities are mapping, and prevention. Mapping the potential for social conflicts is a first step in knowing the potential vulnerability of social conflict to causal factors in a region.

Based on the conflict mitigation process, people can be aware that if a few problems arise in a vulnerable area, it will result in new conflicts and violence between citizens.

Based on the coding results, found 13 forms of mitigation of social conflict, such as education and training, community involvement, regional arrangement, and so forth. This form of social conflict mitigation is presented in Figure 3 below:

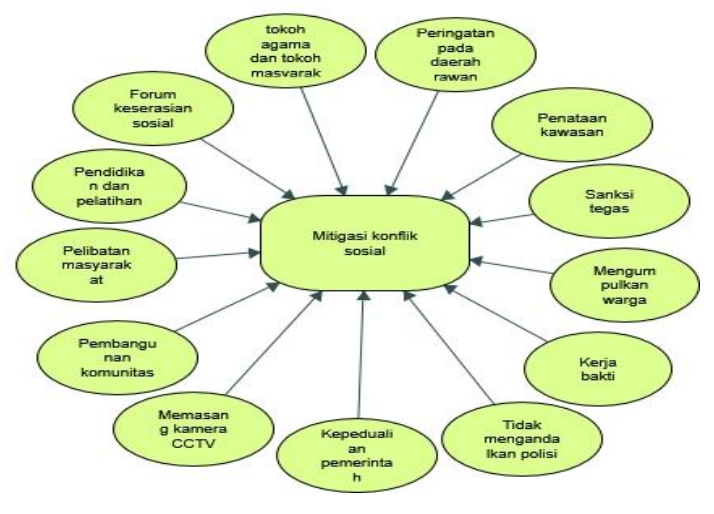

Fig. 3. Forms of Social Conflict Mitigation.

Early detection is very important to be done in mitigating the risk of conflictsocial. Early detection is done to make government officers and citizen more ready in preventing social conflict. The coding results indicate that from various forms of conflict mitigation, it turns out the theme related to community involvement, gathering citizens, religious leaders and community leaders, as well as social harmony forums. This leads to the formation of citizen forums as one of the instruments for mitigating social conflict.

Citizen forum is a form of community participation. Social conflict in Jakarta will never be completed without involving the community to resolve the conflict. Communities involved in the conflict, then the community also have to resolve so that the conflict is not protracted. So far, the space to accommodate community participation is still in minimal number. Through citizen forums, early detection, mapping, and conflict prevention can be done.

Citizen forums in carrying out the task of conflict mitigation are at a central point by doing dialogue with citizens to investigate potential conflicts, accommodate citizens' complaints, oversee the social condition of the community, and at the same time held a discussion to solve problems faced by citizens, so that the problem does not develop into social conflict.

Based on the coding of citizen forums, this study concludes that citizen forums can be meaningful as meeting places, coordinating places, and community activity centers. These places can take the form of a youth forum, early vigilance forum, or citizenship forum. As Sumarto (2009) argues, citizens forums are used to formulate common problems, seek societal disputes-often in the form of recommendations for the government to issue a policy or action, 
as well as a medium of conflict resolution at the local level [16]. The full picture of citizen forums with community activities is presented in Figure 4 below:

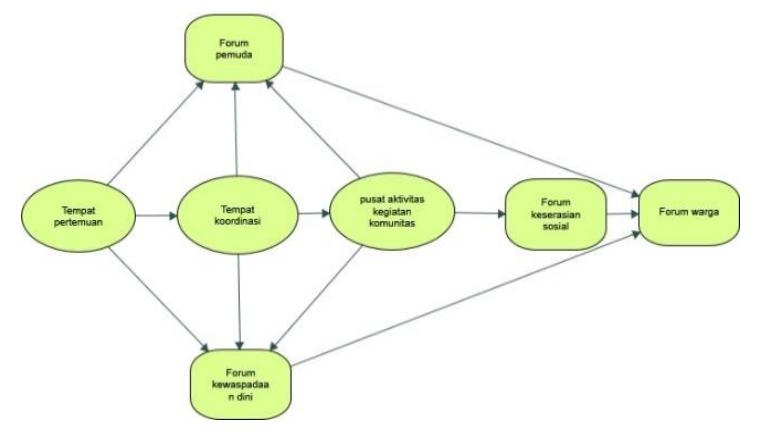

Fig. 4. The relations between the meetings place, the community center with youth forums, early vigilance forums, and social harmony forums.

\subsection{Practice of Communication}

The communication practices found in this study are in the form of counselling, socialization, dialogue, collective action, and information gathering. The communication practice has a final goal, awareness. Awareness is encouraged so that the community can early identify conflict potentials and at the same time to prevent the conflict from spreading. The full picture of the communication practice model is shown in Figure 5:

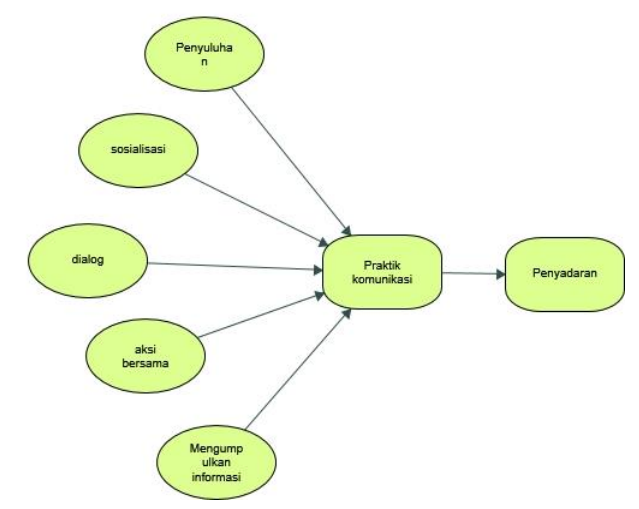

Fig. 5. Communication Practices for Social Conflict Mitigation

Based on the coding result, the practice of participative communication found is dialogue. Dialogue is a communication concerning feedback, so that communicators know whether the communication goes well and in accordance with the audience's expectations or not. Attempts to obtain such feedback are one of them through dialogue. In conflict mitigation, the importance of dialogue is in line with the views of Littlejohn and Domenici (2001), which 
suggest that dialogue is another form of communication that honors relationships over individual perspectives, positions, and interests. Moreover, according to Littlejohn and Domenici (2001), the dialogue aims to help everyone understand the perspectives and experiences of others. Thus, dialogue requires attention to what the communicators make together [17].

Dialogue requires that conflicting parties as well as the authorities (e.g. government or citizen forums) place themselves in a good role in taking position as to understand the problems arises from the conflict, not to impose their own truth or opinion on others and not to simply do impression management through gratuitous appointments, appearances, and other communication tactics that have no impact on conflict resolution.

Mitigation of social conflict requires supporting factors that manifest in the form of communication practices and awareness by citizens. Both can be run through an instrument in the form of community forums. Based on the results of data analysis that researchers done, the relationship between social conflict and its related mitigation is obtained as presented in Figure 6 below:

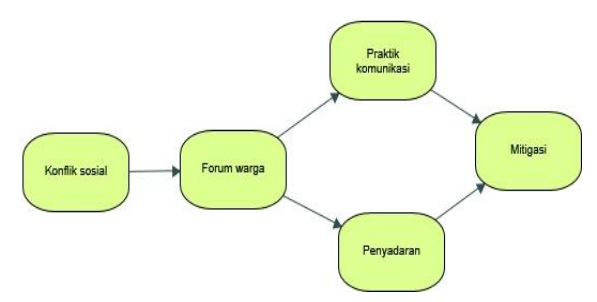

Fig. 6. The Relations of Social Conflict Relation, Citizen Forum, and Conflict Mitigation.

From the picture, the citizen forum has a central point in developing communication practices and providing awareness to the community. Awareness means that the conflicting party has a sincere desire to resolve the conflict, and it cannot be achieved instantly, but through communication practices activated by the citizen forum.

\section{Conclusion}

Mitigation of social conflict is an attempt to identify, map, prevent, and resolve conflict. The practice of communications to mitigate social conflict arecounselling, socialization, collective action, information gathering, and dialogue. 


\section{References}

[1]Badan Kesatuan Bangsa dan Politik DKI Jakarta, "Peta Kawasan Rawan Konflik DKI Jakarta," Jakarta, 2015.

[2]Badan Pusat Statistik, “Jakarta dalam Angka 2016,” Jakarta, 2016.

[3]J. Tadie, Wilayah Kekerasan di Jakarta. Depok: Masup Jakarta, 2009.

[4]S. Sumarno, "Problema dan resolusi konflik sosial di kecamatan johar baru - jakarta pusat," Sosio Konsepsial, vol. 3, no. 2, pp. 1-16, 2014.

[5]Nisa Jakiatin, "Resolusi Konflik dalam Perspektif Komunikasi," Salam, J. Sos. dan Budaya Syar'i, vol. II, no. 1, pp. 17-30, 2015.

[6]H. Ardiyanti, "Manajemen Komunikasi dalam Penanganan Konflik Tarakan," Kajian, vol. 19, no. 1, pp. 33-49, 2014.

[7]J. W. Creswell, Research Design: Pendekatan Metode Kualitatif, Kuantitatif, dan Campuran. Yogyakarta: Pustaka Pelajar, 2016.

[8]H.-F. Hsieh and S. E.Shannon, "Three Approaches to Qualitative Content Analysis," Qual. Health Res., vol. 15, no. 9, pp. 1277-1288, 2005.

[9]S. Elo and H. Kyngäs, "The qualitative content analysis process," J. Adv. Nurs., vol. 62, no. 1, pp. 107-115, 2008.

[10]P. Bazeley, “Analysing Qualitative Data: More than Indentifying Themes,” Malaysian J. Qual. Res., vol. 2, no. 9, pp. 6-22, 2009.

[11]Elaine Welsh, "Dealing with Data: Using NVivo in the Qualitative Data Analysis Process," Qual. Sozialforschung/Forum Qual. Soc. Res., vol. 3, no. 2, 2002.

[12]Alyahmady Hamed Hilal and Said Saleh Alabri, "Using NVivo for Qualitative Data Analysis In Qualitative Research,” Int. Interdiscip. J. Educ., vol. 2, no. 2, pp. 181-186, 2013.

[13]N. L. Leech and A. J. Onwuegbuzie, "Beyond Constant Comparison Qualitative Data Analysis: Using NVivo,” Sch. Psychol. Q., vol. 26, no. 1, pp. 70-84, 2011.

[14]Y. Praharsi, "Pemodelan Data Kualitatif Dengan Program Nvivo ( Studi Kasus: Kegiatan Menulis Dalam Pengajaran Dan Pembelajaran Matematika Diskret )," vol. 2006, no. Snati, 2006.

[15]A. Bandur, Penelitian Kualitatif: Metodologi, Desain, dan Teknik Analisis data dengan NVIVO plus 11. Jakarta: Mitra Wacana Media, 2016.

[16]H. S. Sumarto, Inovasi, Partisipasi, dan Good Governance: 20 Prakarsa Inovatif dan Partisipatif di Indonesia. Jakarta: Yayasan Obor Indonesia, 2009.

[17]S. W. Littlejohn and K. Domenici, Engaging Communication in Conflict: Systemic Practice. Thousand Oaks: Sage Publication, 2001. 